\title{
VASBETON LEMEZEK ÁTSZÚRÓDÁSI MÉRETEZÉ- SÉNEK VÁLTOZÁSA NAPJAINKBAN - 2. RÉSZ: ÁTSZÚRÓDÁSI CSAPOK MÉRETEZÉSE AZ EURÓPAI MUÚSZAKI ENGEDÉLYEK SZERINT
}
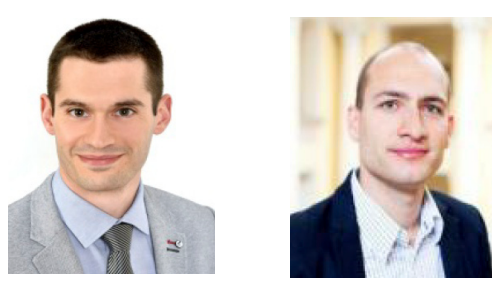

DOl: doi.org/10.32969/VB.2020.3.1

Jobbágy Dávid - Dr. Völgyi István

Jelen cikk célja, hogy áttekintse a siklemezek Eurocode szerinti átszúródási méretezésekor a tervezö rendelkezésére álló módszereket. Emlitést teszünk a kézi módszerekröl, a végeselemes szoftverekbe integrált átszúródási méretezö modulokról és az átszúródási elemeket gyártó cégek méretezö szoftvereiröl. Röviden bemutatjuk az egyes eszközök hátterében futó algoritmusok fö jellemzőit. Ezzel magyarázatot adunk az eredményekben mutatkozó kisebb-nagyobb eltérésekre.

Kulcsszavak: vasbeton, átszúródás, átszúródási csap, EC2, ETA, összehasonlítás

\section{LEGFONTOSABB JELÖLÉSEK}

EC/EC2 MSZ EN 1992-1-1:2001/A1:2016 a vonatkozó hatályos magyar szabvány

MC Model Code 2010

MSZ MSZ 15022/1-2000 Az utolsó MSZ szabvány az EC2 bevezetése elött

$d / d_{\text {eff }} \quad$ az átszúródás vizsgálat szempontjából releváns hasznos magasság

$a, b \quad$ pillér oldalméretei

$\rho_{1} \quad$ húzott hajlítási geometriai vashányad a pillér felett a vasbeton lemezben

$\beta \quad$ tehernövelö tényezö

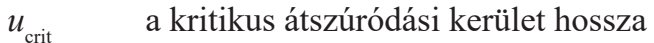

$u_{\text {out }} \quad$ a külső átszúródási kerület hossza, ahol már nincs szükség átszúródási vasalásra

$V_{\mathrm{Ed}} \quad$ az átszúró erő tervezési értéke

$V_{\mathrm{Rdc}} \quad$ beton által felvehető átszúró erő tervezési értéke

$V_{\mathrm{Rds}} \quad$ vasalás által felvehető átszúró erő tervezési értéke

$V_{\mathrm{Rdcs}}^{\mathrm{Rds}} \quad$ vasalás és beton által felvehető átszúró erő tervezési értéke

$V_{\text {Rdmax }} \quad$ átszúródási teherbírás felső korlátja

Jelen cikk egy két cikkből álló sorozat második része. A cikksorozat célja, hogy áttekintse vasbeton lemezek átszúródási méretezése területén a közelmúltban bekövetkezett, illetve a közeljövőben várható változásokat és azok hatását. Az első cikk az Eurocode bevezetése előtti Magyar Szabvány (MSZ), az Eurocode (EC2) és a Model Code (MC) méretezési algoritmusainak bemutatására és a tipikus alkalmazások esetén várható eredmények elemzésére koncentrál. Megvizsgáltuk néhány tipikusnak tekinthető közbenső vasbeton födém és alaplemez átszúródási ellenállását a három tárgyalt szabvány ismeretében. Összehasonlítottuk az adott vasalással készülő lemezek figyelembe vehető teherbírását, illetve az adott lemezvastagság (és hajlítási vasalás) esetén elérhető maximá- lis átszúródási ellenállást. A különböző szabványok szerinti teherbírás értékekre vonatkozó legfontosabb megállapítások a következők:

- A beton által felvehető átszúró erő rész - még a 75\%-os redukció figyelembe vételével is - az EC2 esetében a legnagyobb.

- A nagyobb hatékony feszültség miatt gyakran magasabb az átszúródási vasalás MC szerinti ellenállása, a figyelembe vett vasak alacsonyabb száma ellenére is.

- Bár a MC esetében a vasalás által felvehető erő gyakran jóval nagyobb, mégis az EC2 szerinti teherbírás lesz magasabb, mert a MC szerinti felső korlát gyakran korlátozza azt.

- AMC a legszigorúbb az átszúródási teherbírás felső korlátja tekintetében, bár megjegyezzük, hogy a számításokban használt $k_{\mathrm{sys}}=2.8$ érték az utóbbi években végzett kísérletek szerint akár a 3.8-at is elérheti. Ennek bevezetése esetén jelentősen megnőhet a felső korlát értéke. Az EC2 módosítása jelentős szigorítást jelent a kis $d / b$ arányú lemezek esetében. Egyedül a nagy vastagságú lemezek vizsgálatakor fordul elő EC2 esetében, hogy közepes és magas teherszinten is a vasalás teherbírása a mértékadó.

- A cikksorozat első részében közölt táblázat néhány eleme tévesen jelent meg, ezért az érintett lemezek számítási eredményeit megismételjük (1. táblázat).

Jelen cikk a tervező rendelkezésére álló eszköztárakat elemzi. Bemutatjuk a módszerek mögött álló algoritmusokat, az egyes eszközök előnyeit, hátrányait és korlátait.

\section{A TERVEZŐ LEHETŐSÉGEI - A MÉRETEZÉSI MÓDSZEREK FŐ JELLEMZŐI}

Magyarországon a vasbeton síklemez födémek méretezése alapvetően az EC2 szerint történik. Az EC2 által nem kezelt 
1. táblázat: a kidolgozott esetek eredményei $\left(\mathrm{k}_{\max }=2.0 \mathrm{k}_{\mathrm{sys}}=2.0\right.$ bal oldalt; $\mathrm{k}_{\max }=2.5 ; \mathrm{k}_{\mathrm{sys}}=2.8$ jobb oldalt - csak a változó mennyiségeket ismételtük meg)

\begin{tabular}{|c|c|c|c|c|}
\hline \multirow{5}{*}{ 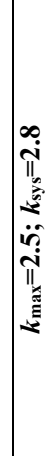 } & [Ny] ${ }^{\mathrm{H}} \boldsymbol{L}$ & ¿ ๙ & ڤ̊ñ & 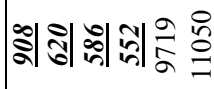 \\
\hline & 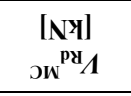 & 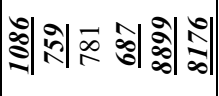 & 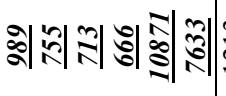 & 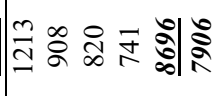 \\
\hline & $\begin{array}{c}\text { [Ny] } \\
\text { py/A } \\
\mathrm{pa}^{2} /\end{array}$ & 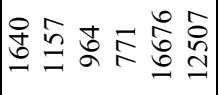 & 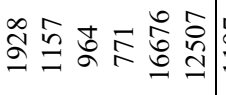 & 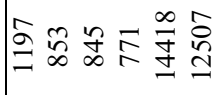 \\
\hline & $\underset{\text { xहupy } / \text { [Ny] }}{[\mathrm{N}}$ & 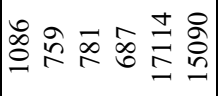 & 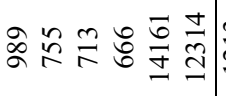 & 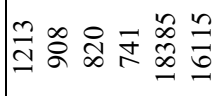 \\
\hline & 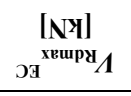 & 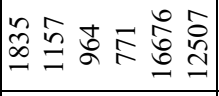 & 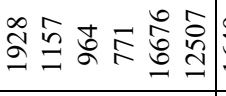 & 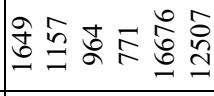 \\
\hline \multirow{22}{*}{ 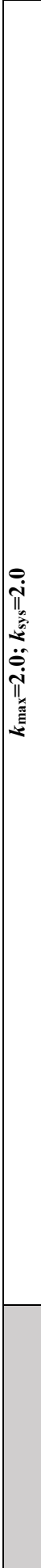 } & {$[\mathrm{Ny}]{ }^{\mathrm{H}} \boldsymbol{L}$} & ৪ & 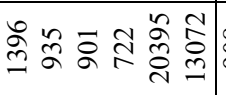 & 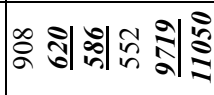 \\
\hline & $\begin{array}{c}\text { [Ny] } \\
\text { Jw }^{\text {py } \Lambda}\end{array}$ & 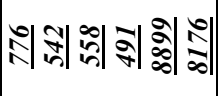 & 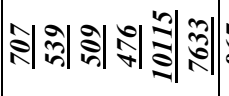 & 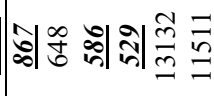 \\
\hline & $\underset{\mathrm{py}}{[\mathrm{NY}]}$ & 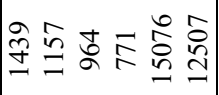 & 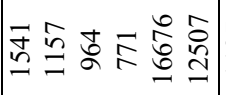 & 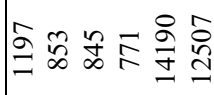 \\
\hline & {$[\mathrm{NY}]{ }^{{ }^{\mathrm{H}} \mathrm{L}} \boldsymbol{L}$} & 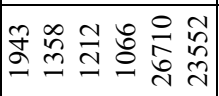 & 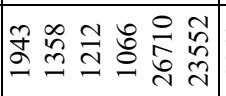 & 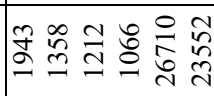 \\
\hline & $\underset{\substack{\text { xeupy } \\
\text { JN }}}{\text { [Ny] }}$ & 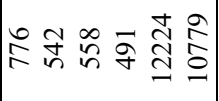 & $\hat{}$ ڤે & 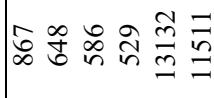 \\
\hline & 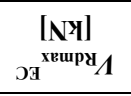 & 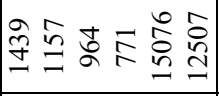 & 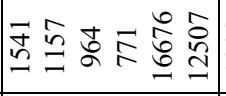 & 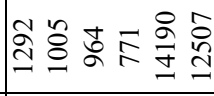 \\
\hline & {$[\mathbf{N Y}]{ }^{{ }^{{ }^{2}} \mathrm{H}} \boldsymbol{L}$} & 음 & ڤั & 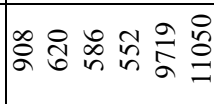 \\
\hline & $\underset{\text { sspy }}{[\mathrm{NYl}}$ & 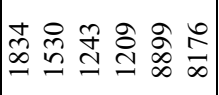 & 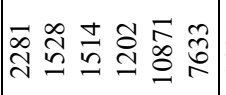 & 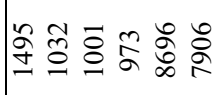 \\
\hline & 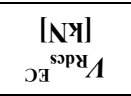 & 웡 & 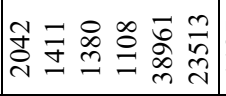 & 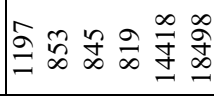 \\
\hline & [NY] ${ }^{{ }^{\mathrm{SH}} \boldsymbol{L}}$ & 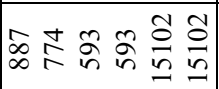 & 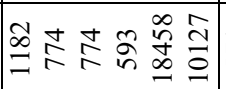 & 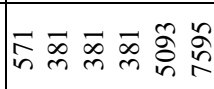 \\
\hline & 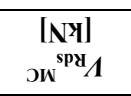 & 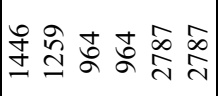 & 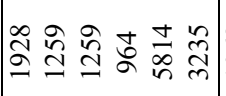 & 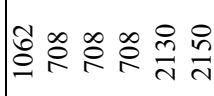 \\
\hline & 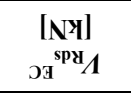 & 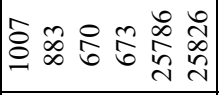 & 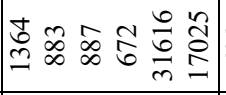 & 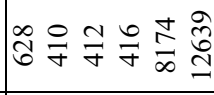 \\
\hline & {$[\mathrm{Ny}]{ }^{{ }^{B}}{ }_{H} L$} & 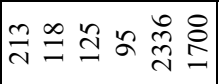 & 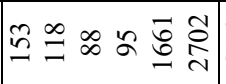 & 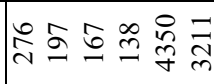 \\
\hline & $\begin{array}{c}{[\mathrm{Ny}]} \\
\mathrm{Jw}^{\mathrm{py} / \Lambda}\end{array}$ & 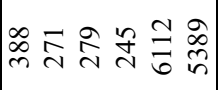 & 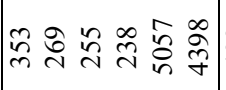 & \\
\hline & 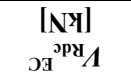 & 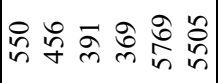 & 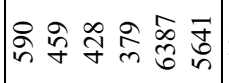 & 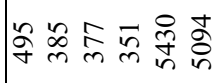 \\
\hline & $\begin{array}{l}\text { [uw] } \\
\text { ZSN } n\end{array}$ & 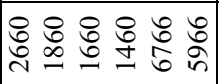 & 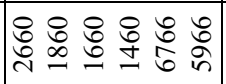 & $\begin{array}{l}8 \\
:\end{array}$ \\
\hline & $\begin{array}{l}\text { [wய] } \\
\text { כwn }\end{array}$ & 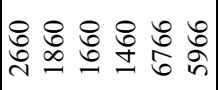 & 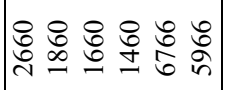 & 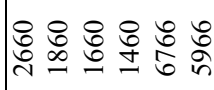 \\
\hline & [шш] Оэ & 它 & 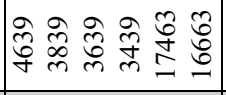 & 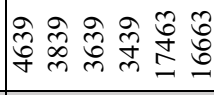 \\
\hline & {$[\%]^{I d}$} & 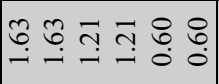 & 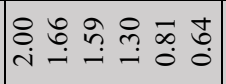 & 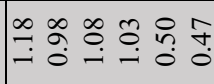 \\
\hline & {$[-] \mathrm{g} / \boldsymbol{p}$} & 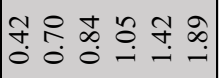 & 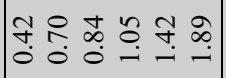 & 界 \\
\hline & $\begin{array}{l}{[\omega \omega]} \\
y^{\wedge} p^{\prime} p\end{array}$ & 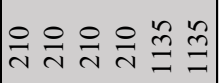 & $\stackrel{\circ}{\sim} \stackrel{0}{\sim} \stackrel{ }{\sim} \stackrel{ }{\sim} \stackrel{n}{=} \stackrel{n}{=}$ & 읏으스을 \\
\hline & [uய & ৪ \& & \& 8 : & \& \& \\
\hline
\end{tabular}

átszúródási vasalási típusokat (pl. zömített fejü csapok) pedig az ún. ETA dokumentumok (European Technical Approval Európai Müszaki Engedély) alapján kell méretezni. Ezeknek a dokumentumoknak mindig EC2 konformnak, vagyis annak útmutatásaival összehangoltnak kell lenniük.

Ebben a fejezetben a leggyakrabban használt méretezési módszerek jellemzőit gyüjtöttük össze. Az EC2 és ETA-k szerinti méretezési eljárások összevetését a következő fejezet tartalmazza.

A tervezőknek a gyakorlatban az alábbi lehetőségei vannak a méretezés elvégzésére:

- kézi számítás

- végeselemes programok beépített moduljai (pl. AxisVM, FemDesign)

- gyártói szoftverek (pl. Schöck Bole, Halfen HDB, Halfen Filigran, Peikko PSB, Jordahl JDA).

\subsection{Kézi számítás}

A kézi módszerek alatt a tervezés/ellenőrzés kézzel, esetleg általános célú táblázatkezelő vagy matematikai szoftverekkel (pl. Excel, Mathcad, stb.) történő elvégzését értjük. Ez többnyire a bevasalhatóság gyors ellenőrzését és a jellemző kerületen (kerületeken) szükséges vasmennyiség kiszámolását jelenti. Gyakran csak a legszükségesebb adatokat vesszük ezekkel figyelembe (geometria, hajlítási vashányad, terhelö erő, anyagminőség), a számítást bonyolító hatásokat gyakran elhanyagoljuk (pl. nyomatékok hatása a nyírófeszültség egyenlőtlen eloszlásra, födémáttörések, szerkesztési szabályok figyelembe vétele, stb.). Az EC2 nem szabályozza, hogy végeselemes számítás és nem pontszerű támasz esetén hogyan emelje ki a tervező az átszúró erőt a statikai számításból. Ugyanakkor ez a módszer biztosítja a legnagyobb rugalmasságot, különleges esetek is kezelhetők. Gyakorlatilag bármilyen EC2 szerinti átszúródási vasalási típus és elrendezés számítható, a kézi számítás lehetőséget ad továbbá a tervezőnek a mérlegelésre (pl. 101\%-os kihasználtság „elfogadása”, tényezők, vasalás kialakítás tervezői mérlegelés szerinti megváltoztatása, stb.).

A kézi számítás algoritmusát nem tárgyaljuk részletesen, hiszen az a cikksorozat első részében bemutatott eljárás szerint történik.

\subsection{Végeselemes programok beépített moduljai}

A végeselemes programokba épített modulok előnye, hogy a geometriát (födémáttörések) és a terhelést (egyidejü nyomatékok) is képes pontosabban figyelembe venni, illetve ezeket a program automatikusan átveszi a számítási modellből. Hátrányuk, hogy sokszor rugalmatlanok, tervezői mérlegelésre nem adnak lehetőséget. Mindkét tárgyalt modul képes több tervezési szabvány szerint számolni.

Az AxisVM számító és méretező program modulja a tervező által kiválasztott részleteket ellenőrzi a modellben számított igénybevételek alapján. Az alapadatok megadása után a program az összes teherkombinációt figyelembe véve ellenőrzi a bevasalhatóságot és meghatározza a kerületenként szükséges vasmennyiséget. Az AxisVM nem ad tényleges vasalási kiosztást, ezért többlet tervezői munka szükséges.

A FemDesign moduljában ki lehet választani az átszúródási vasalás típusát (átszúródási sámli, felhajlított vas, zömített fejü csap, stb.), illetve a program képes vasalási elrendezést is adni. A cikk írásakor elérhető verzió alkalmas a Peikko PSB zömített fejü csapok tervezésére. Ez a gyártói szoftverekhez hasonló módon, a Peikko ETA-ja alapján történik és azokkal 
többnyire azonos megoldást ad (a modul optimalizálása még folyamatban van).

A beépített modulok számítási algoritmusát sem tárgyaljuk részletesen, mivel az is a cikksorozat első részében bemutatott eljárás szerint történik.

\subsection{Gyártói szoftverek}

A termékspecifikus gyártói szoftverek a vonatkozó ETA-k alapján számolnak és minden esetben az adott termékre „optimalizáltak”. Ellenőrzik az átszúródás elleni bevasalhatóságot, továbbá konkrét vasalási elrendezést is adnak, ami a tervekre közvetlenül átvihető. A geometria és a terhek mellett további, a termékre jellemző adatokat is meg kell adni. A legtöbb szoftver több tervezési szabvány szerinti tervezést is lehetővé tesz.

A gyártói szoftverek esetében - a kézi módszerekhez hasonlóan - manuálisan kell a mértékadó igénybevételeket a végeselemes számításból kiemelni. Általában lehetőség van az áttörések kezelésére. Ugyanakkor - a végeselemes szoftverek moduljaihoz hasonlóan - nincs lehetőség az elöre nem programozott esetek kezelésére.

\subsection{Gyártói szoftverekről részlete- sebben}

Ahogy korábban említettük, a zömített fejü átszúródási csapok tervezését nem az EC2 alapján kell elvégezni. Pontosabban fogalmazva: az EC2 szerint a zömített fejü csapokkal mint átszúródási vasalással ellátott födémek esetén a vasalás által felvehető erőt $\left(V_{\text {Rd.s }}\right)$ az ETA-k alapján kell meghatározni. Vagyis az átszúródási méretezés lépései és gondolatmenete EC2 szerinti, de néhány részlet különbözik.

Az ok, hogy az EC2 a zömített fejjel történő lehorgonyzást nem ismeri, az hogy az nincs benne a betonacélok lehetséges lehorgonyzási módjai között (8.5. fejezet és 8.5. ábra). Az itt bemutatottaktól eltérő lehorgonyzási módok esetén az EC2 a termékszabványhoz vagy az ETA-hoz irányítja a tervezőt (8.4.1. (5)).

A következőkben a zömített fejü csap gyártók szoftvereinek számítási eljárását ismertetjük és ennek segítségével össze is vetjük az EC2 és az ETA-k átszúródási méretezési eljárását. A vizsgált gyártók a Schöck, a Peikko és a Halfen. Meglepő, de a tárgyalt termékek ETA dokumentumai az átszúródási csapok méretezésének vonatkozásában megegyeznek. Ennek oka a szerzők előtt nem ismert.

\section{AZ ÁTSZÚRÓDÁSI MÉRETEZÉS MENETE GYÁRTÓI SZOFTVEREK SZERINT}

Az átszúródási csapok tervezését födémek esetére ismertetjük. Alaplemezek, alaptestek esetén az eljárás hasonló.

A méretezés elvégzéséhez az alábbi adatok szükségesek: hatékony magasság $\left(d_{\text {eff }}\right)$; oszlop keresztmetszeti méretei $(a, b)$; betonfedés $\left(c_{\text {nom }}\right)$; betonszilárdság $\left(f_{\mathrm{ck}}\right)$; betonacél szilárdság $\left(f_{\text {yd }}\right)$; hajlítási vasmennyiség az oszlop felett $\left(\rho_{1}\right)$; tehernövelö tényező $(b)$; átszúró erö $\left(V_{\mathrm{Ed}}\right)$.

A geometria, az anyagszilárdságok és a mértékadó átszúró erő felvételét az ETA-k nem részletezik, azt EC2 alapján kell elvégezni.

Az átszúródási vasalás tervezése az alábbi lépések szerint zajlik:

a) Az átszúródási vasalás szükségességének vizsgálata. Az átszúródási vasalás szükségességének és a beton által felvehető fajlagos nyíróerőnek $\left(v_{\mathrm{Rd}, \mathrm{c}}\right)$ a számítása követi az EC2-t. Egyetlen eltérés a $C_{\mathrm{Rd}, \mathrm{c}}$ szorzónál van, amit az ETA-k kis keresztmetszetü pillérek $\left(u_{0} / d_{\text {eff }}<4\right)$ esetén csökkentenek (van olyan EC2 nemzeti melléklet, pl. a német DIN EN 1992-1-1:2015/ NA:2015, ami tartalmazza a $C_{\mathrm{Rd}, \mathrm{c}}$ paraméter csökkentését). Tekintve, hogy az ETA-k a szabvány egyfajta kiegészítéseként müködnek, a szoftverekben mindig meg kell adni, hogy melyik szabványhoz használjuk őket. Ez okozza azt, hogy ugyanaz a program ugyanarra az esetre eltérő megoldást nyújthat, ha a szabvány különbözik, annak ellenére, hogy a termék ETA-ja mindkét esetben ugyanaz. A beton által felvehetö nyíróerö képlete (részletek nélkül):

$V_{R d, c}=\left(C_{R d, c} \cdot k \cdot\left(100 \cdot \rho_{l} \cdot f_{c k}\right)^{1 / 3}+k_{1} \cdot \sigma_{c p}\right) \cdot u_{1} \cdot d_{e f f} \geq\left(v_{\min }+k_{1} \cdot \sigma_{c p}\right) \cdot u_{1} \cdot d_{e f f}$

A $C_{R d, \mathrm{c}}$ szorzó $u_{0} / d_{\text {eff }}<4$ esetén:

$C_{R d, c}=\frac{0.18}{\gamma_{c}} \cdot\left(0.1 \frac{u_{0}}{d_{e f f}}+0.6\right) \geq \frac{0.15}{\gamma_{c}}$

b) Az átszúródási teherbírás felső korlátjának (vagyis az átszúródás elleni bevasalhatóság) vizsgálata. Ez az ellenőrzés az oszloptól $2 d_{\text {eff }}$ távolságra lévő kerületen történik. Az ellenőrzés alapja a beton által felvehető fajlagos nyíróerő $\left(v_{\mathrm{Rd.c}}\right)$, melyet egy konstanssal szorozva és a kritikus kerületen összegezve kapjuk az átszúródási teherbírás felső korlátját (lásd a lenti képletet). Az ETA-k egységesen 1.96-nak veszik ezt a konstanst. Érdemes észrevenni, hogy a lenti kifejezés nagyon hasonló az EC2-ben szereplö $k_{\max } V_{\text {Rd.c }}$ összefüggéshez, amivel EC2 a $V_{\text {Rd,cs }}$ értékét maximalizálja. Fontos különbség, hogy az ETA-k nem írják elő a feltámaszkodás kerületén $\left(u_{0}\right)$ a nyomott beton rácsrúd tönkremenetelének ( $\left.V_{\text {Rd.max }}\right)$ ellenörzését, mivel az arra használt szabványos képlet számos kísérlet szerint a biztonság kárára téved (összesen 45 különböző kutatók által elvégzett kísérlet, 1. pl. Ricker 2014, illetve már jóval korábban is Elstner 1956 és Moe 1961). Megjegyzendő, hogy ez egyfajta inkonzisztencia az ETA-k és az EC2 között, hiszen az utóbbi csak a $V_{\text {Rd,cs }}$ értékének számítását sorolja az ETA-k ,jogkörébe”, ugyanakkor van olyan eset, amikor $V_{\text {Rd.max }}$ adja a mértékadó felső korlátot. A szerzők megítélése szerint az lenne helyes, ha az ETA-k is a $V_{\mathrm{Rd}, c s}$ korlátjaként vezetnék be ezt a képletet, nem pedig $V_{\mathrm{Rd} \text { max }}$ helyett. Ha a szabvány másképp nem rendelkezik, akkor mindkét felső korlátot ellenőrizni kell(ene). A magyar EC2 szerinti ellenőrzésnél mindkettő korlát vizsgálata szükséges, míg a korábban említett német szabvány csak az $u_{1}$ kerületen történő ellenőrzést írja elő. Tehát a kiválasztott szabványtól függően a gyártói szoftverek is figyelembe vehetik a nyomott beton rácsrúd tönkremeneteléhez tartozó korlátot. Itt megjegyezzük, hogy az EC2 $V_{\text {Rdmax }}$ ellenőrzését a feltámaszkodás kerületén írja elő, és az ehhez a kerülethez tartozó $v_{\mathrm{Rd} \text { max }}$ számítását a nemzeti mellékletek hatáskörébe sorolja. A szóban forgó német nemzeti melléklet ezt felülírja és az ellenőrzést az $u_{1}$ kerületre írja elő az ETA-k képletéhez hasonló összefüggéssel.

Az ETA-k szerinti $V_{\text {Rd,max }}$ képlet, ami az ellenőrzött kerület és az algoritmus tekintetében sem felel meg az EC2 szerinti $V_{\text {Rd,max }}$ összefüggésnek:

$V_{R d, \max }=1.96 \cdot V_{R d, c}$

c) A szükséges vasmennyiség számítása és a szerkesztési szabályok szerinti kiosztása. A gyártói szoftverek az alábbi módon határozzák meg a szükséges vasmennyiséget:

- Annak a kerületnek a meghatározása ahol már a beton nyírási teherbírása elegendö $\left(u_{\text {out }}\right)$ : 


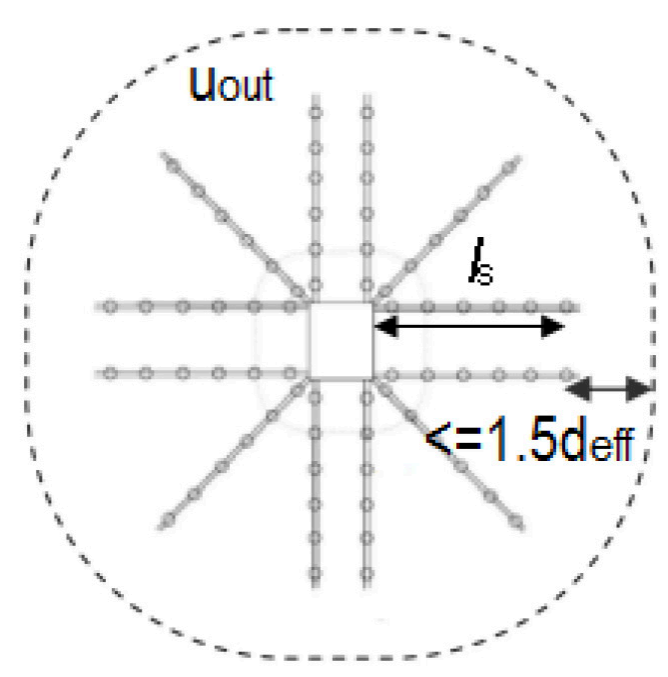

1. ábra: a külső kerület és a legutolsó csapsor távolságára vonatkozó korlát (Qualität im Bauwesen-előadás, Michael Kammerer-Schöck, 2013.11.26.)

$u_{\text {out }}=\frac{\beta V_{E d}}{v_{R d, c} d_{e f f}}$

- Az átszúródásra vasalandó zóna széle oszloptól mért távolságának meghatározása ( $l$-a legutolsó csap oszlop kerülettől mért távolsága, lásd 1. ábra). Ez abból a szerkesztési szabályból indul ki, hogy a legutolsó csap külső kerülettől mért sugárirányú távolsága ne legyen nagyobb, mint $1.5 d_{\text {eff* }}$

$l_{s}=\frac{u_{o u t}-2(a+b)}{2 \pi}-1.5 d_{e f f}$

- Az egy csapsoron lévő csapok számának meghatározása. Ehhez szükség van az $S_{\mathrm{w} 1}$ és $S_{\mathrm{w} 2}$ távolságokra (2. ábra), melyeknek értékét az ETA-k (és a szabványok is) bizonyos korlátok közé szorítják. Födémeknél:

$$
0.35 d_{\text {eff }} \leq s_{w 1} \leq 0.5 d_{e f f} ; s_{w 2} \leq 0.75 d_{e f f}
$$

Ezek segítségével az egy csapsoron lévő csapok száma:

$n_{A}=\frac{l_{s}-s_{w 1}}{s_{w 2}}+1$

Az így kapott értéket kell felfelé, egészre kerekíteni és ez adja meg a szükséges csapszámot. Az $s_{\mathrm{w} 1}$ és $s_{\mathrm{w} 2}$ távolságokat a szoftverek valamelyest eltérően veszik fel, illetve kerekítik (pl. egyik 5 cm-re, másik cm-re kerekít). Emiatt lehetnek eltérések az alkalmazott csapszámokban (lásd a következő fejezetet).

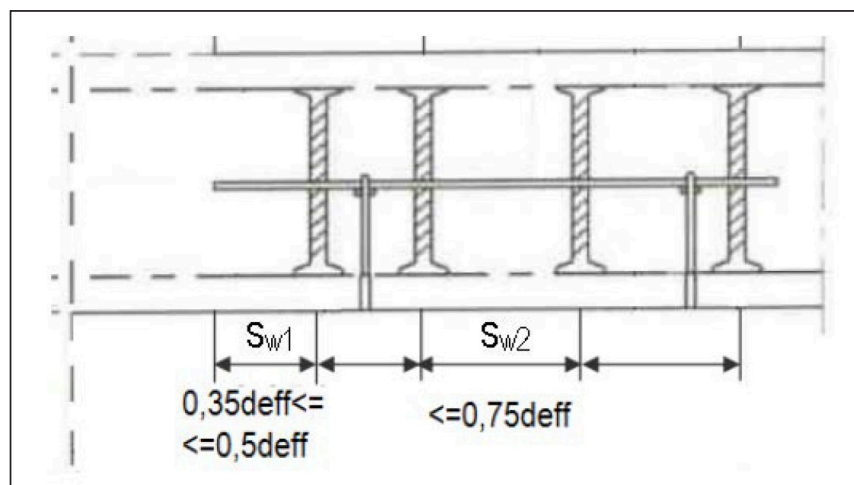

2. ábra: a csapok távolságára vonatkozó szerkesztési szabályok (Qualität im Bauwesen-előadás, Michael Kämmerer-Schöck, 2013.11.26.)
- A csapsorok elrendezésének meghatározása alapvetően a szerkesztési szabályok alapján történik. A „C” zóna a feltámaszkodástól $a_{\mathrm{c}}=1.125 d_{\text {eff }}$ távolságra lévő kerület által határolt rész (3. ábra). Á szerkesztési szabályok meghatározzák a „C” zóna külső kerületén és a legkülső kerületen lévő csapok érintő irányú maximális távolságát. Ezzel szemben az EC2 a legbelső (a pillérhez legközelebbi) csapsorra írja elő az érintőirányú távolságot (4. ábra). Az ETA-k elöírják, hogy a „C” zónában minimum kettő darab csap legyen csapsoronként, ez pedig akár felül is írhatja az $\mathrm{s}_{\mathrm{w} 2}$ távolságot. Ennek jelentőségét a következő pontban tárgyaljuk.

A szoftverek által támogatott csapsor elrendezések egyszerübb esetekben többnyire megegyeznek, de kisebb eltérések (főleg bonyolultabb esetekben, pl. födémáttöréseknél) előfordulnak.

- A szükséges csapátmérő $\left(d_{c s a p}\right)$ meghatározása. Az előző pontok alapján láthattuk, hogy a gyártói szoftverek először a csapsorok elrendezését határozzák meg. Vagyis a szükséges vasmennyiség számítását megelőzi az átszúródási vasalás szerkesztési szabályoknak megfelelö kiosztása. Ez eltér az átszúródási méretezés EC2 tárgyalása szerinti sorrendjétől, de nem mond ellent neki.

A szükséges csapátmérő meghatározása abból a feltételből indul ki, hogy a korábban említett „C” zónán belüli csapoknak ( $n \mathrm{db})$ kell felvenniük az egész átszúró eröt:

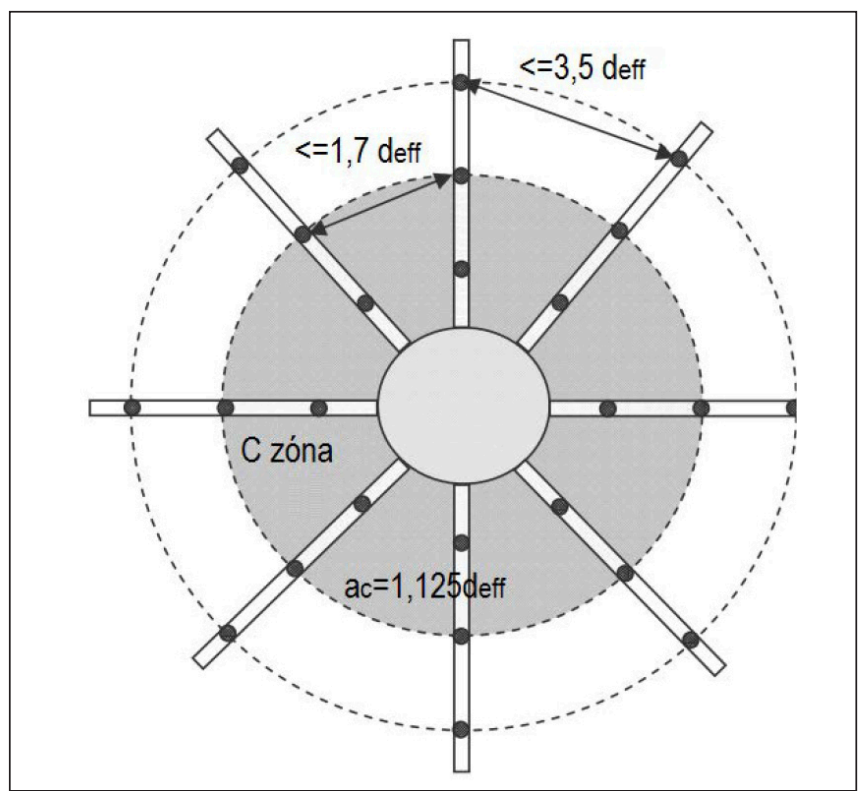

3. ábra: szerkesztési szabályok a gyártmányok ETA-ja szerint (ETA 13/0076 alapján)

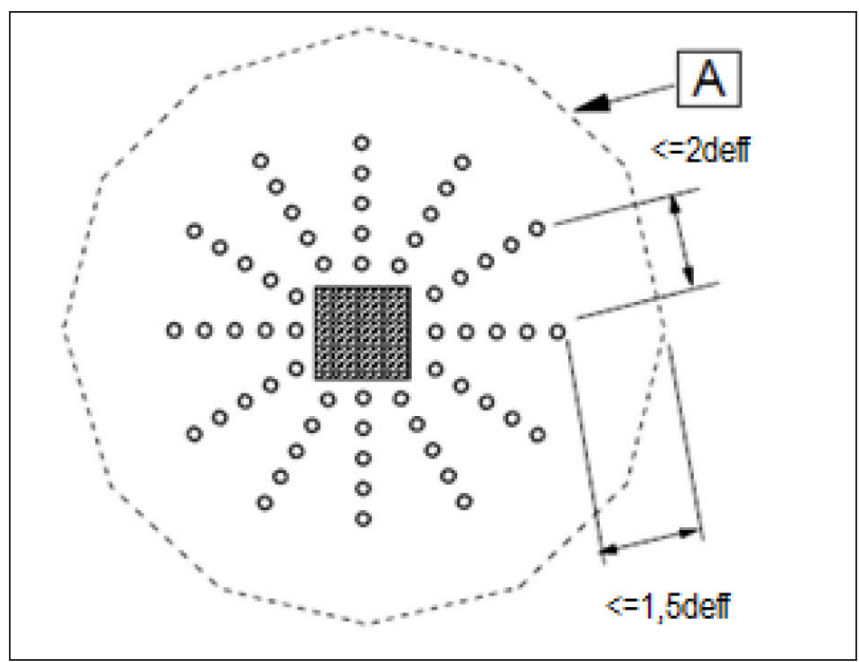

4. ábra: szerkesztési szabályok EC2 szerint (MSZ EN-1992-1-1 6.22 ábra alapján) 
$d_{c s a p}=\sqrt{\frac{\beta \cdot V_{E d} \cdot 4 \cdot \eta}{n \cdot \pi \cdot f_{y d}}}$, ahol:

Közbenső értékeknél lineáris interpoláció alkalmazandó.

Ha ez alapján túl nagy átmérő adódik, akkor a szoftverek az elrendezést módosítják: vagy plusz csapsort tesznek be, vagy pedig a sugárirányú csaptávolságot csökkentve növelik a „C” zónán belüli csapszámot.

Az EC2 a hagyományos átszúródási vasalás típusoknál az alábbi összefüggést használja a vasalás által felvehető erő meghatározására:

$V_{R d, c s}=0.75 \cdot v_{R d, c} \cdot d_{e f f} \cdot u_{1}+1.5 \frac{d_{e f f}}{s_{w 2}} A_{s w} \cdot f_{y w d, e f f} \cdot \sin \alpha$

Ebből a szükséges vasmennyiség számolható.

Ebben a pontban jelentősen eltér a két módszer. A legfontosabb különbségek az alábbiak:

- Az ETA-k nem veszik figyelembe a beton teherbírását. Az ETA-kat megalapozó kísérletek szerint a tönkremenetelhez közeli állapotban az átszúró eröt szinte teljes egészében az átszúródási csapok viselik, a beton hozzájárulása elhanyagolható (Ricker 2014).

- Az EC2 szerint nem lehet az acél folyáshatárával számolni, egy ún. effektív acélfeszültséget definiál, ami lemez a hasznos magasságától függ. Az ETA-k a teljes folyáshatárral számolnak mivel a kísérletek szerint az első két csapsorban a feszültség a legtöbb esetben eléri a folyáshatárt.

- Az átszúródási vasalás elrendezésére vonatkozó szerkesztési szabályokban is van eltérés. Az ETA-k az utolsó kerületen sokkal megengedőbb elöírást alkalmaznak az érintő irányú távolságra $\left(3.5 d_{\text {eff }}\right)$, mint az EC2 $\left(2 d_{\text {eff }}\right)$. Azonban - ahogy korábban említettük - az ETA-k elöírják, hogy a „C” zónában legalább két csap legyen csapsoronként, illetve a zóna határához legközelebb eső csap kerületen is elöírnak maximális érintő irányú távolságot $\left(1.7 d_{\text {eff }}\right)$. A külső csapok és az $u_{\text {out }}$ kerület közötti sugárirányú távolságot hasonlóan $1.5 d_{\text {eff }}$-ben maximalizálják. Megjegyezzük, hogy bár az EC2 átszúródási csapok esetén az ETA-khoz irányítja a tervezőt, a szerkesztési szabályokat mégis sugárirányban kiosztott csapokon magyarázza. Az egyéb, nem sugárirányban kiosztott átszúródási vasalás típusoknál sokszor nehezen értelmezhetők ezek a szerkesztési szabályok. Szükséges továbbá megjegyeznünk azt is, hogy az EC2 9.4.3 fejezetében további szerkesztési szabályokat is találunk, azonban nem egyértelmü, hogy azok általánosan érvényesek-e vagy pedig csak bizonyos átszúródási vasalás típusok esetén kell őket alkalmazni. Ilyen például a legkisebb átszúródási kerületen (oszloptól $2.0 d_{\text {eff }}$ távolságra lévő kerület) a csapok érintő irányú távolságára előírt $1.5 d_{\text {eff }}$ távolság. A szabvány szerint ez a kengyelszárak távolságára vonatkozik (tehát átszúródási csapokra nem), lehajlított vasak esetén pedig figyelmen kívül is hagyja. A szerkesztési szabály a 6.22 ábrán sem szerepel. Ugyanakkor az általánosan ismert és (ETA-k szerint is) alkalmazott $0.75 d_{\text {eff }}$ sugárirányú távolságot is kengyelszárakból kialakított vasalási kerületekre írja elő. A kidolgozott példáinkban a legkisebb átszúródási kerületre vonatkozó (egyébként rendkívül szigorú) $1.5 d_{\text {eff }}$ távolságot ezért figyelmen kívül hagytuk.

Összefoglalásként elmondhatjuk, hogy a gyártói szoftverek számítási eljárása alapvetően három részből áll:

- átszúródási vasalás szükségességének vizsgálata

- az átszúródási teherbírás felső korlátjának vizsgálata

- az átszúródási vasalás mennyiségének és elrendezésének meghatározása.

Az első két pontban alig van eltérés az EC2-höz képes, azonban a harmadik pontban jelentős különbségeket találunk, melyek közül a legfontosabb a beton teherbírásának figyelmen kívül hagyása, az átszúródási vasalásban ébredő feszültség és az átszúródási teherbírásban hatékonyan résztvevő csapok számának kérdése. Ugyanakkor a külső vassor esetében alkalmazott lényegesen megengedőbb szerkesztési szabály sok esetben a csapok számának jelentős csökkentését teszi lehetővé. Ez az előregyártott átszúródási elemek versenyképessége szempontjából igen jelentős részlet.

\section{KÜLÖNBÖZŐ MÓDSZEREKKEL MEGHATÁROZOTT ALKALMA- ZOTT VASALÁSOK}

Ebben a fejezetben azt vizsgáljuk, hogy a különböző szoftverek milyen vasalási elrendezést adnak ugyanazon oszlop esetén. Mivel a számítási eljárás a vizsgált szoftvereknél azonos (hiszen a számítás alapjául szolgáló dokumentumok is lényegében megegyeznek), joggal várhatjuk, hogy egy adott tervezési feladat esetén nagyon hasonló eredményeket kapjunk.

E célból a cikksorozat első részében vizsgált esetekből kiválasztottunk, egy $50 \times 50 \mathrm{~cm}$-es közbenső szinti belső, és egy $20 \times 20 \mathrm{~cm}$-es tetőszinti belső pillért. Ezekhez az esetekhez a hazánkban legjobban ismert csapgyártók szoftverével (Schöck Bole, Halfen HDB, Peikko PSB) megterveztük a vasalást, majd a kapott elrendezést és a számítási részeredményeket összevetettük.

Az eredmények alapján az alábbi megállapításokat tehetjük:

- A vizsgált esetekben a különböző szoftverek nagyon hasonló átszúródási vasalási elrendezést adtak. A csapok és csapsorok száma, valamint a csapátmérő mindhárom szoftver esetében azonos volt. A csapsorok alaprajzi elrendezése is megegyezett. Ehhez kapcsolódóan megjegyezzük, hogy némelyik szoftver a szokásostól eltérő vasalási elrendezést is támogat, ami esetenként kevesebb csapsort is jelenthet. Természetesen a csapsor szám csökkentésének minden esetben határt szabnak a szerkesztési szabályok.

- A csapok oszloptól és egymástól mért távolságai mindhárom szoftvernél különbözőek voltak $\left(s_{\mathrm{w} 1}, s_{\mathrm{w} 2}\right)$. Ennek az oka, hogy a szerkesztési szabályokban rögzített minimális és maximális távolságot másféleképpen veszik fel és másféleképpen is kerekítik. Ez nüansznyi eltérés, egyes konkrét esetekben mégis jelentős hatással lehet az alkalmazott csapszámra. Ennek okai a következők:

○ A szoftverek az egy csapsoron szükséges csapszámot (vagyis a csapsor hosszát) az $s_{\mathrm{w} 1}, s_{\mathrm{w} 2}$ csap távolságok és az átszúródásra vasalandó zóna sugarának hossza $\left(l_{\mathrm{s}}\right)$ alapján számítják ki. Ez azt jelenti, hogy kisebb $s_{\mathrm{w} 1}, s_{\mathrm{w} 2}$ értékek esetén a szükséges csapszám is nőhet, még akkor is, ha maga az eltérés kicsi.

○ Az $s_{\mathrm{w} 1}$ és $s_{\mathrm{w} 2}$ értékek határozzák meg azt is, hogy az utolsó csap hova kerül (vagyis milyen messze az oszlopfejtől). A szerkesztési szabályok rögzítik az utolsó csapkörön lévő csapok közötti maximális érintőirányú távolságot, így ha az utolsó csap messze van a pillértől (és így az érintő irányú távolság az adott csapkörön nagy) ez plusz csapsor elhelyezését eredményezi.

Az $50 \times 50 \mathrm{~cm}$ oldalméretü pillérhez generált vasalásokat a szoftverekböl kimentett vázlatok segítségével mutatjuk be (5. ábra - 7. ábra):

A szoftverek a vasalást diszkrét lépésekben változtatják, ezért egy adott átszúró erőre tervezett vasalás ismeretében nem határozható meg közvetlenül, hogy az adott szoftver pontosan milyen teherbírást rendel hozzá. Megvizsgáltuk, hogy ha változtatjuk (növeljük vagy csökkentjük) az átszúró 


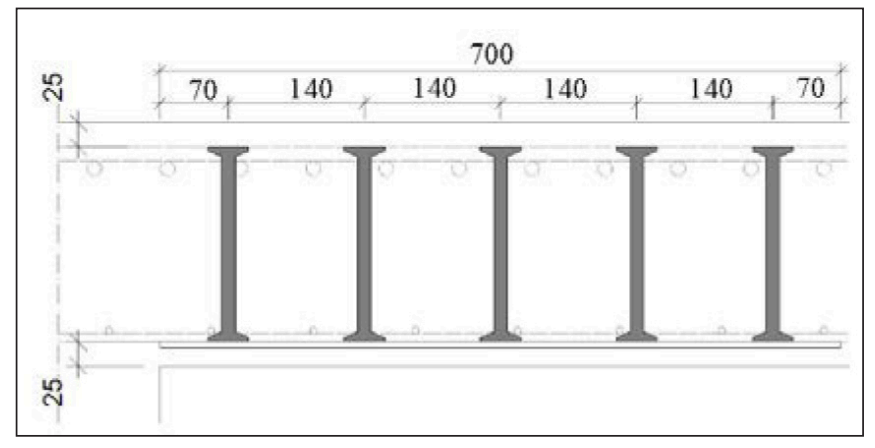

5. ábra: Schöck Bole: 12 csapsor, soronként 5 db Ø14 csappal

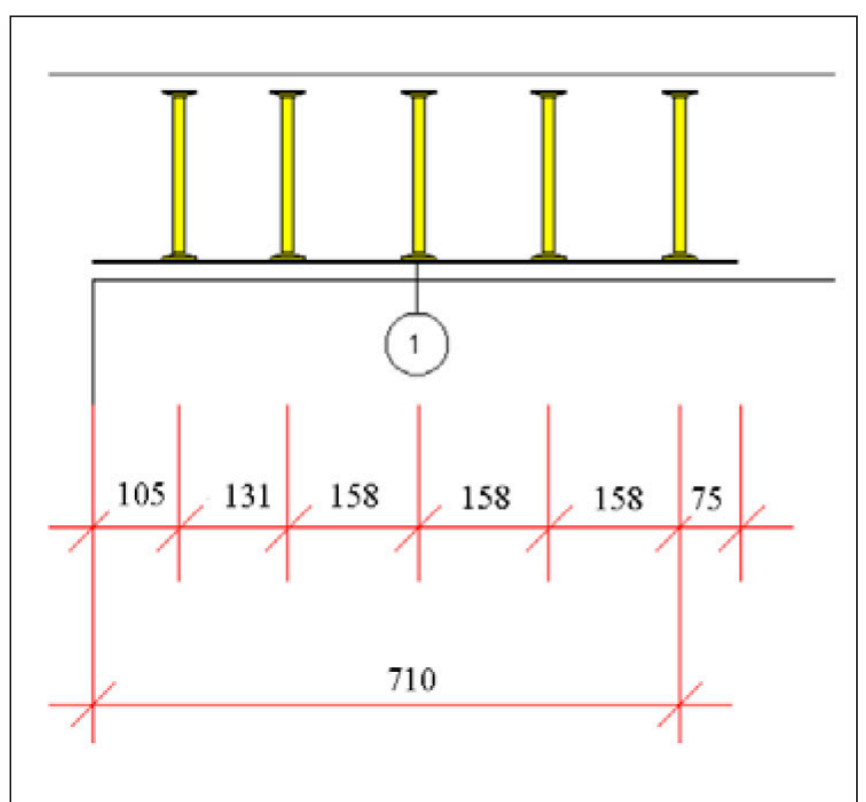

6. ábra: Halfen HDB: 12 csapsor, soronként 5 db $\varnothing 14$ csappal

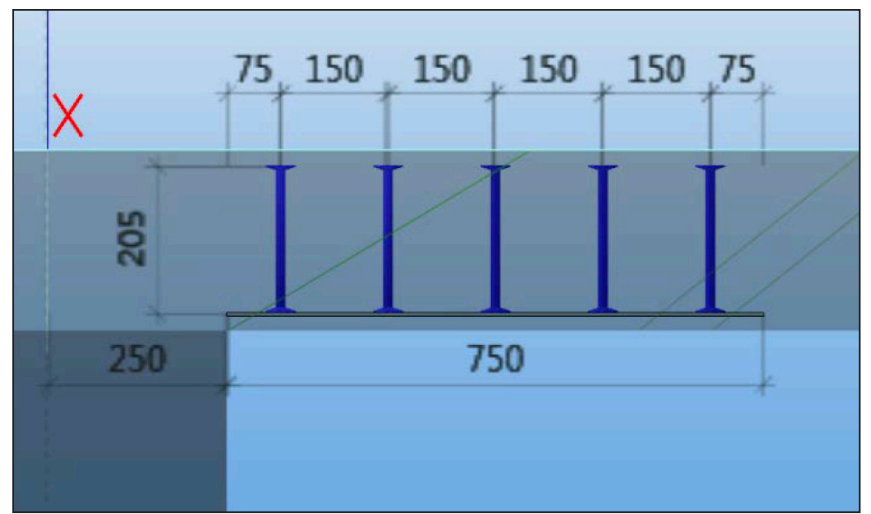

7. ábra: Peikko Designer: 12 csapsor, soronként 5 db Ø14 csappal

erőt, akkor melyik szoftver milyen erőnél módosítja a vasalást. Az összevethetőség kedvéért ugyanezt elvégeztük az EC2 elöírásai szerint is. Az eredményeket az alábbi táblázatban foglaltuk össze:

2. táblázat: $A z 1200$ kN átszúró erőre tervezett alkalmazott vasalás teherbírás tartománya (50×50 cm pillér).

\begin{tabular}{|l|c|c|}
\hline \multirow{2}{*}{\multicolumn{1}{|c|}{ Szoftver }} & $\begin{array}{c}\text { Edodeti átszúró erő: } \mathrm{V}_{\mathrm{Ed}}=1200 \mathrm{kN} \\
\text { rendelt maxiáshoz } \\
\text { átszúró erő }[\mathrm{kN}]\end{array}$ & $\begin{array}{c}\text { Adott vasaláshoz rendelt } \\
\text { minimális átszúró erő } \\
{[\mathrm{kN}]}\end{array}$ \\
\hline Schöck Bole & 1257 & 1117 \\
\hline Halfen HDB & 1302 & 1153 \\
\hline Peikko Designer & 1336 & 1178 \\
\hline $\begin{array}{l}\text { EC2 szerinti kézi } \\
\text { számítás }\end{array}$ & 1243 & 1151 \\
\hline
\end{tabular}

3. táblázat: A 700 kN átszúró erőre tervezett alkalmazott vasalás teherbírás tartománya ( $20 \times 20 \mathrm{~cm}$ pillér).

\begin{tabular}{|l|c|c|}
\hline & \multicolumn{2}{|c|}{ Eredeti átszúró erő: $\mathrm{V}_{\mathrm{Ed}}=700 \mathrm{kN}$} \\
\hline \multicolumn{1}{|c|}{ Szoftver } & $\begin{array}{c}\text { Adott vasaláshoz } \\
\text { rendelt maximá- } \\
\text { lis átszúró eró } \\
{[\mathrm{kN}]}\end{array}$ & $\begin{array}{c}\text { Adott vasaláshoz } \\
\text { rendelt minimális } \\
\text { átszúró erő }[\mathrm{kN}]\end{array}$ \\
\hline Schöck Bole & 714 & 677 \\
\hline $\begin{array}{l}\text { Halfen HDB } \\
\begin{array}{l}\text { Peikko Designer } \\
\text { (ill. FEM Design } \\
\text { modul) }\end{array}\end{array}$ & 737 & 677 \\
\hline $\begin{array}{l}\text { EC2 szerinti } \\
\text { kézi számítás }\end{array}$ & 711 & 677 \\
\hline
\end{tabular}

A csapsorok száma, a csapszám és a csapátmérő táblázatonként változatlan. Látható, hogy valamelyest más teherszinteknél változik a vasalás az egyes szoftvereknél. Ez alól csak a $20 \times 20 \mathrm{~cm}$-es pillér kivétel és az is csak az erő csökkentése esetén. Ennek az a magyarázata, hogy a többi esetben a szerkesztési szabályok miatt változik a kiosztás egy bizonyos teherszinten (pl. erő növelése esetén több csapsor kell, mert távolodik a külső kerület, viszont ez minden szoftver esetén más teherszinten következik be az eltérő $s_{\mathrm{w} 1}, s_{\mathrm{w} 2}$ távolságok miatt). A $20 \times 20 \mathrm{~cm}$-es pillér és alsó korlát esetben pedig nem lehetett a szerkesztési szabályok miatt csökkenteni a csapszámot csak az átmérőt. Az pedig független az $s_{\mathrm{w} 1}, \mathrm{~s}_{\mathrm{w} 2}$ távolságoktól, ezért kapunk mindhárom esetben azonos eredményt. Az EC2 szerinti kézi számítás, ahogy fentebb megmutattuk, néhány pontban jelentősen különbözik az ETA-k szerintitől, ennek ellenére hasonló eredményre vezet. Az AxisVM szoftver jelenlegi verziója nem ad vasalási elrendezést, ezért azt nem vettük bele az összehasonlításban.

\section{4. ÖSSZEFOGLALÁS}

Cikkünk áttekintette a leggyakrabban alkalmazott átszúródási méretező módszerek elönyeit, hátrányait, algoritmusát. Minden fejezetben következtetéseket fogalmaztunk meg. Itt a legfontosabbakat emeljük ki.

Rámutattunk a gyártói méretező szoftverek EC2-től való eltérésére. Néhány tipikus példa segítségével bemutattuk az egyes módszerek által szolgáltatott eredmények kis különbségeit, és az eltérések okait. Megmutattuk, hogy az elvi eltérések ellenére a vizsgált tipikus esetekben a bekerülési költségre jelentős hatással bíró darabszám tekintetében csekély az eredmények eltérése. Ugyanakkor rámutattunk, hogy a gyártói szoftverek lényegesen megengedőbbek a külső csapsorok távolsága tekintetében, ami nagy vasalandó zóna esetén számottevően kevesebb vasalási elemet eredményezhet, mint az EC2 közvetlen alkalmazása.

\section{IRODALMI HIVATKOZÁSOK}

AxisVM X5 Felhasználói kézikönyv, 2019.02.27.

CEN-DIN: DIN EN 1992-1-1:2004/A1:2014 Eurocode 2: Bemessung und Konstruktion von Stahlbeton- und Spannbetontragwerken - Teil 1-1: Allgemeine Bemessungsregeln und Regeln für den Hochbau.

CEN-MSZT: MSZ EN 1992-1-1:2004/A1:2016 Eurocode 2: Betonszerkezetek tervezése: Általános és épületekre vonatkozó szabályok.

DIN EN 1992-1-1/NA/A1:2015. Nationaler Anhang - National festgelegte Parameter - Eurocode 2: Bemessung und Konstruktion von Stahlbetonund Spannbetontragwerken - Teil 1-1: Allgemeine Bemessungsregeln und Regeln für den Hochbau. 
Elstner R. C., Hognestad E. (1956): Shearing Strength of Reinforced Concrete Slabs. ACI Journal. Proceedings 53. pp.29-58.

Europäische Technische Zulassung ETA-12/0454: HALFEN HDB Dübelleiste: Doppelkopfanker als Durchstanzbewehrung. Deutsches Institut für Bautechnik (DIBt), Berlin, Dezember 2012.

Europäische Technische Zulassung ETA-13/0076: Durchstanzbewehrung Schöck Bole: Durchstanzbewehrung mit Doppelkopfbolzen für punktförmig belastete Platten und Fundamente. Deutsches Institut für Bautechnik (DIBt), Berlin, März 2013

Europäische Technische Zulassung ETA-13/0151: PEIKKO PSB Durchstanzbewehrung: Doppelkopfanker als Durchstanzbewehrung. Deutsches Institut für Bautechnik (DIBt), Berlin, April 2013.

FEM Design 18 User manual

Moe J. (1961): Shearing Strength of Reinforced Concrete Slabs and Footings under Concentrated Loads. Bulletin D47, Portland Cement Association.

Qualität im Bauwesen-előadás, Michael Kammerer-Schöck, 2013.11.26.

Ricker M., Häusler F. (2014): Europäische Bemessungsregeln für Doppelkopfanker als Durchstanzbewehrung. Beton- und Stahlbetonbau 109. pp.30-42. https://doi.org/10.1002/best.201300056
Jobbágy Dávid: okleveles építőmérnök (2016), Zentrale Technik, tartószerkezeti tervező.

Dr. Völgyi István: okleveles építőmérnök (2002), Betontechnológiai szakmérnök (2009), PhD (2011), a BME Hidak és Szerkezetek Tanszék docense. Kapcsolódó kutatási területek: vasbeton rúdszerkezetek nyírási viselkedése, vasbeton lemezek átszúródási viselkedése. A fib Magyar Tagozat tagja

DEVELOPMENT OF DESIGN CODES FOR PUNCHING DESIGN OF REINFORCED CONCRETE SLABS - PART 2.: DESIGN OF DUPBLE HEADED STUDS ACCORDING TO THE EUROPEAN TECHNICAL APPROVAL

Dávid Jobbágy - István Völgyi

In this paper the different tools available for the structural engineer for the punching design of reinforced concrete slabs are analysed. Hand calculation methods, design moduls of commercial FE analysis and design programs and softwares of double headed stud manufacturers are mentioned. The main features of these tools are discussed. Then, the algorithm of the sofwares of the stud manufacturers are in more details analysed. On this basis, conclusions regarding the differences in the results are drawn. 